\title{
COMPLEXITY OF THE GLACIAL PERIOD, AND IOWA'S ROLE IN ITS ESTABLISHMENT.
}

Although Louis Agassiz's theory of continental glaciation was one of the most brilliant generalizations of modern science, it was neither so complete nor so widely applicable as was at first supposed. What was even more important to its scientific value than the bare statement of the conception itself was the recognition of the fact that there was not one but many glacial epochs in the earth's history. Of course Croll's hypothesis urged the necessity of successive glacial periods, but it was soon shown that his astronomical dates were too far apart to account for the vicissitudes of the epoch which we are now mainly studying. So we have to go back to the testimony of the glacial deposits themselves for our fundamental data.

In the great world-wide controversy which warmly waged for more than a generation, Iowa chanced to bear a conspicuous part. It was in Iowa that the first real evidences were found indicating the multiple instead of the unal character of the glacial epoch. They were Iowa men who made this great discovery. In Iowa were finally differentiated not one but five great glacial drift-sheets, or deposits, marking the successive advancement of the vast fields of northern continental ice. On Iowa men chiefly devolved the responsibility of first working out the complete and genetic relationships of these remarkable glacial till-mantles. Today the Iowa classification of the Great Ice Age is accepted for the whole world.

In order fully to appreciate the genuine importance of the Towa results bearing upon glacial complexity as opposed to glacial unity the facts leading up to the birth of the idea may be briefly reviewed. So early as 1870 Edward Orton observed peat-beds in the glacial deposits of Ohio, and he rightly concluded that this feature indicated a warm interglacial epoch. He stated that evidence was at hand for the orderly arrangement of post-Tertiary deposits. This dual aspect of the glacial debris was further substantiated by 
Leverett, Chamberlain, Gilbert, McGee and others. In the prolix discussion which followed on the duality of the Glacial period the real facts were overlooked or misinterpreted and the possibility of a multiple instead of either an unal or dual Ice age was lost sight of. Once suggested the multiple hypothesis, about the year 1893, rapidly gained general acceptance among scientific men.

The arguments for a dual Glacial period and at the time of its proposal for a multiple Ice age were based mainly upon the fact of the presence in till-sections of thin black soil streaks, replaced here and there by thicker peat-beds. That there might be extensive interglacial sand or clay deposits was not thought of. Yet they were actually recorded and described a full decade prior to the time when their true significance was pointed out. Such an interglacial deposit clearly intercalated between two great till-sheets is the one on Capitol Hill in Des Moines, described in detail by $\mathrm{W}$ J McGee in 1882." It seems to be the first one ever recorded the stratigraphic relations of which were unmistakable.

C. K.

\section{N.TES.}

The First National Bank of Davenport, Iowa, commemorative of the completion of the fiftieth year of its present legal status, published a volume which is entitled to more consideration than that given a mere record of financial development of a community. The foreword by the President of the Bank, Hon. A. F. Dawson, is a chapter on the banking history both of Iowa and the country at large:

In presenting this little volume to the public the aim has been to set forth in concise form the facts leading up to the establishment of the first bank which opened its doors for business under the National Bank Act of 1863 , together with a history of its progress for the half century of its existence, and to make plain the marked

${ }^{3}$ American Journal of Science, v. 24, pp. 202-23. 
Copyright of Annals of Iowa is the property of State of Iowa, by \& through the State Historical Society of Iowa and its content may not be copied or emailed to multiple sites or posted to a listserv without the copyright holder's express written permission. However, users may print, download, or email articles for individual use. 